УДк 633.15:631.52

DOI 10.36461/NP.2020.54.1.008

\title{
ОПТИМИЗАЦИЯ УРОВНЯ ВЛАГООБЕСПЕЧЕННОСТИ ПОЧВЫ ПРИ ВЫРАЩИВАНИИ САХАРНОЙ КУКУРУЗЫ
}

И. М. Ханиева, доктор с.-х. наук, профрессор; С. А. Бекузарова*, доктор с.-х. наук, профрессор; З. Г. С. Шибзухов, канд. с.-х. наук, доцент; Т. С. Виндугов, аспирант

Федеральное государственное бюджетное образовательное учреждение высшего образования «Кабардино-Балкарский государственный аграрный университет»,

Россия, г. Нальчик, e-mail: imhanieva@mail.ru;

*Федеральное государственное бюджетное образовательное учреждение высшего образования «Горский государственный аграрный университет», Россия, г. Владикавказ, e-mail: bekos37@mail.ru

Работа выполнена в условиях предгорной зоны Кабардино-Балкарского района при недостаточном и неустойчивом увлажнении. Для опытов использовались современные системы капельного орошения. По результатам опытов видно как орошение влияет на развитие и продуктивность растений сладкой кукурузы. В исследованиях использовали пять вариантов уровня орошения. После проведения анализа полученных данных выявили наиболее оптимальную норму орошения и рекомендовали использовать в дальнейшем при производстве сахарной кукурузы. Наблюдения показали, что в начале вегетации фазы роста у растений сахарной кукурузы проходили на всех вариантах одинаково, появление всходов отмечалось за годы исследований на 8-11 сутки. В дальнейшем, с изменением условий влагообеспеченности наблюдалось различие в датах наступления основных фаз вегетации. На втором варианте фразы роста практически совпадали с контрольным вариантом, но фазы цветения початков и технической спелости увеличились на одни сутки. На третьем и четвертом вариантах основные фразы вегетации сократились на 1-2 суток в сравнении с контролем. На варианте без орошения шло наиболее ускоренное развитие этой культуры, и техническая спелость наступила на 4-7 суток раньше, чем на других вариантах опыта. Прибавка урожая от уровня орошения следовала той же закономерности - с уменьшением уровня соответствия количества получаемой влаги потребностям растений величина получаемой прибавки урожая снижалась. На контрольном варианте прибавка урожая товарных початков от орошения составила 9,6 т/га или 89 \%, в т. ч. зерна - 4,18 т/га или 94 \%, а на втором варианте она возросла соответственно до 12,3 и 5,55 т/га, что в процентном отношении составило 114 и $125 \%$.

Ключевые слова: влагообеспеченность, развитие растений, сахарная кукуруза, урожайность, выживаемость растений, межфазные периоды.

\section{Введение}

Систему капельного орошения придумали около 65 лет назад и до сих пор она остается одним из самых эффективных методов полива практически для всех сельскохозяйственных культур. В сравнении с дождеванием в среднем при капельном орошении расход поливной воды снижается в два раза, при этом появление водной эрозии на склоне исключается. Преимущества системы в ее работе как в автоматическом (в заданные промежутки времени), так и постоянном режиме, что особенно важно для широкорядных посевов. При капельном орошении междурядья не заливаются, и влага успевает впитаться глубже в почву [1].

Целью наших исследований являлось определение эфффективности выращивания растений сахарной кукурузы в условиях предгорной зоны КБР при различных режимах и нормах орошения.

\section{Методы и материалы}

При обильном орошении быстрее развиваются болезни и вредители растений. Для разработки технологии производства сахарной кукурузы с применением капельного орошения нами закладывались полевые опыты по определению оптимальных режимов полива и поливных норм.

1 вариант: влажность почвы 80 \% НВ в почвенном слое до 0,6 м (контроль).

2 вариант: влажность почвы 80 \% НВ в почвенном слое до 0,4 м.

3 вариант: влажность почвы $65 \%$ HВ в почвенном слое до 0,6 м (до фазы начала цветения початков), с доведением до $80 \%$ HB. 
4 вариант: влажность почвы $70 \%$ НВ в почвенном слое 0,6 м (до фазы начала выметывания метелки), с доведением до $80 \%$ HB.

5 вариант: Без полива.

Площадь делянки 50 м², повторность опытов - четырехкратная.

Суммарное водопотребление рассчитывали методом водного баланса по формуле А. Н. Костякова [2] (1960) при глубоком залегании грунтовых вод:

$$
W=\left(V_{1}-V_{2}\right)+P+M,
$$

где $\mathrm{W}$ - суммарное водопотребление культуры, м³/га; $V_{1}$ - весенний запас влаги в метровом слое почвы перед посевом, м /га; $\mathrm{y}_{2}$ - запас влаги в метровом слое почвы перед уборкой $\mathrm{M}^{3} /$ га; P - эфффективные осадки свыше 5 мм, м³/га; M - оросительная норма, $\mathrm{m}^{3} /$ га.

Коэффрициент водопотребления определяли путем деления суммарного водопотребления на урожай по формуле

$$
\mathrm{K}=\frac{W}{Y},
$$

где К - коэффицциент водопотребления, м³ т; Y - урожайность, т/га

\section{Результаты}

Для орошаемого земледелия одной из важнейших задач является определение рационального водного режима сельскохозяйственных культур, при котором обеспечивается наивысшая продуктивность гектара орошаемых земель при наименьших расходах воды на единицу урожая. Бесперебойное снабжение растений сахарной кукурузы влагой в течение вегетационного периода и экономное расходование поливной воды может быть достигнуто только при определенном режиме орошения.

Густота стояния растений является одним из условий формирования высокой урожайности, так как определяет оптимальную площадь питания растений. Учет густоты всходов и числа растений при уборке, который проводился в годы исследований, свидетельствует о том, что режим орошения влияет на их выживаемость.

В среднем за три года выживаемость растений на контрольном варианте составила $96 \%$. Проведение более частых поливов меньшими нормами на втором варианте опыта обеспечило 98 \% их выживаемости. На третьем и четвертом вариантах с дифференцированным режимом орошения при снижении влажности почвы соответственно до 65 и 70 \% НВ создавались более жесткие условия увлажнения растений, что способствовало снижению их выживаемости до 92 и 94 \%. Наименьшая выживаемость - $86 \%$ отмечена на варианте без орошения. Большее изреживание этих растений происходило под влиянием недостатка влаги в почве, о чем свидетельствовала более светлая окраска листьев, а в жаркие дни наблюдалось сильное их завядание.

Фенологические наблюдения занимают важное место среди исследований биологического роста растений. На основе их определяется продолжительность вегетационного периода растений. Изучение влияния режима орошения на даты наступления основных фаз роста сахарной кукурузы приведено в таблице 1.

Наблюдения показали, что в начале вегетации фразы роста у растений сахарной кукурузы проходили на всех вариантах одинаково - появление всходов отмечалось за годы исследований на 8-11 сутки. В дальнейшем, с изменением условий влагообеспеченности наблюдалось различие в датах наступления основных фаз вегетации. На втором варианте фразы роста практически совпадали с контрольным вариантом, но фразы цветения початков и технической спелости увеличились на одни сутки. На третьем и четвертом вариантах основные фазы вегетации сократились на 1-2 суток в сравнении с контролем. На вариан-

Таблица 1

Выживаемость растений в зависимости от уровня орошения, 2017-2019 2.

\begin{tabular}{|l|c|c|c|}
\hline \multicolumn{1}{|c|}{ Вариант } & \multicolumn{2}{|c|}{$\begin{array}{c}\text { Количество } \\
\text { растений, } \\
\text { тыс. шт. / га }\end{array}$} & $\begin{array}{c}\text { Выжива- } \\
\text { емость, } \\
\%\end{array}$ \\
\cline { 2 - 3 } & Всходы & Уборка & \\
\hline 1. Влажность почвы 80 \% НВ в почвенном слое до 0,6 м (контроль) & 62,7 & 60,2 & 96 \\
\hline 2. Влажность почвы 80 \% НВ в почвенном слое до 0,4 м & 62,7 & 61,4 & 98 \\
\hline \begin{tabular}{l|c|c|} 
3. Влажность почвы 65 \% НВ в почвенном слое 0,6 м \\
(до фразы начала цветения початков), с доведением до 80 \% НВ
\end{tabular} & 62,6 & 57,6 & 92 \\
\hline $\begin{array}{l}\text { 4. Влажность почвы 70 \% НВ в почвенном слое 0,6 м (до фразы } \\
\text { начала выметывания метелки), с доведением до 80\% НВ }\end{array}$ & 62,7 & 58,9 & 94 \\
\hline 5. Без полива & 62,6 & 53,8 & 86 \\
\hline
\end{tabular}


Продолжительность основных межфразных периодов в зависимости от режима орошения, 2017-2019 2.

\begin{tabular}{|c|c|c|c|c|c|c|}
\hline Вариант & 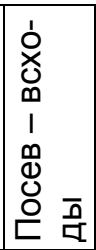 & 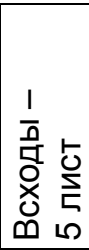 & 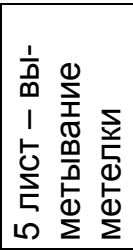 & 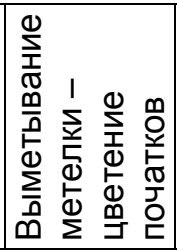 & 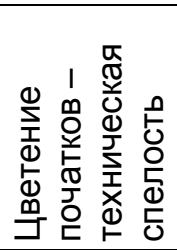 & 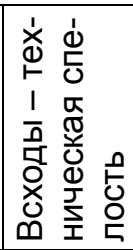 \\
\hline $\begin{array}{l}\text { 1. Влажность почвы } 80 \text { \% НВ в почвенном } \\
\text { слое до 0,6 м (контроль) }\end{array}$ & 9 & 12 & 40 & 11 & 13 & 76 \\
\hline $\begin{array}{l}\text { 2. Влажность почвы } 80 \text { \% НВ в почвенном } \\
\text { слое до } 0,4 \text { м }\end{array}$ & 9 & 12 & 40 & 12 & 13 & 77 \\
\hline $\begin{array}{l}\text { 3. Влажность почвы } 65 \text { \% НВ в почвенном } \\
\text { слое 0,6 м (до фазы начала цветения по- } \\
\text { чатков), с доведением до } 80 \text { \% НВ }\end{array}$ & 9 & 12 & 39 & 11 & 12 & 74 \\
\hline $\begin{array}{l}\text { 4. Влажность почвы } 70 \text { \% НВ в почвенном } \\
\text { слое 0,6 м (до фразы начала выметывания } \\
\text { метелки), с доведением до } 80 \text { \% НВ }\end{array}$ & 9 & 12 & 40 & 11 & 12 & 75 \\
\hline 5. Без полива & 9 & 12 & 36 & 10 & 12 & 70 \\
\hline
\end{tabular}

те без орошения шло наиболее ускоренное развитие этой культуры, и техническая спелость наступила на 4-7 суток раньше, чем на других вариантах опыта.

Установлено, что на контроле и на втором варианте опыта, где влажность почвы поддерживалась в пределах 80-100 \% HB, продолжительность межфазных периодов увеличивалась. Например, период вегетации (всходы-техническая спелость) на этих вариантах в среднем за годы исследований составил 76 и 77 суток соответственно. На третьем и четвертом вариантах с дифференцированным режимом орошения он сократился до 74-75 суток, а на варианте без орошения до 70 суток (табл. 2).

Таким образом, при орошении основные фразы роста и развития сахарной кукурузы, по сравнению с вариантом без орошения, наступают позднее, увеличивается вегетационный период и длина межфазных периодов, которые тем больше, чем выше предполивной порог влажности почвы.

Условия влагообеспеченности опреде- лили величину урожая товарных початков, в том числе зерна сахарной кукурузы. На контрольном варианте при поддержании влажности почвы в слое 0,6 м в пределах 80-100 \% НВ урожай товарных початков в среднем за годы исследований составил 20,4 т/га, в т. ч. зерна - 8,62 т/га. На втором варианте при уменьшении глубины промачиваемого слоя почвы до 0,4 м получен наибольший урожай товарных початков 23,1 т/га, в т. ч. зерна - 9,99 т/га. При снижении влажности почвы до $65 \%$ НВ на третьем варианте и до 70 \% НВ на четвертом варианте недобор урожая товарных початков составил соответственно 4,8 и 3,2 т/га или 24 и $17 \%$, в т. ч. зерна - 2,29 и 1,46 т/га или 27 и $17 \%$. На варианте без орошения потери урожая товарных початков составили 9,6 т/га, в т. ч. зерна - 4,18 т/га или 47 и $48 \%$.

Прибавка урожая от орошения следовала той же закономерностью - с уменьшением уровня соответствия количества получаемой влаги потребностям растений

Таблица 3

Урожайность зерна сахарной кукурузы в зависимости от режима орошения, 2017-2019 2., m/2a

\begin{tabular}{|c|c|c|c|c|}
\hline \multirow[b]{2}{*}{ Вариант } & \multicolumn{3}{|c|}{ Урожайность } & \multirow{2}{*}{$\begin{array}{c}\text { Средняя } \\
\text { урожай- } \\
\text { ность }\end{array}$} \\
\hline & I & II & III & \\
\hline 1. Влажность почвы 80 \% НВ в почвенном слое до 0,6 м (контроль) & 8,10 & 9,12 & 8,65 & 8,62 \\
\hline 2. Влажность почвы 80 \% НВ в почвенном слое до 0,4 м & 9,52 & 10,59 & 9,87 & 9,99 \\
\hline $\begin{array}{l}\text { 3. Влажность почвы } 65 \% \text { НВ в почвенном слое 0,6 м (до фазы } \\
\text { начала цветения початков), с доведением до } 80 \% \text { HВ }\end{array}$ & 5,74 & 6,80 & 6,47 & 6,33 \\
\hline $\begin{array}{l}\text { 4. Влажность почвы } 70 \text { \% НВ в почвенном слое 0,6 м (до фазы } \\
\text { начала выметывания метелки), с доведением до } 80 \% \text { НВ }\end{array}$ & 6,62 & 7,58 & 7,29 & 7,16 \\
\hline 5. Без полива & 3,78 & 5,10 & 4,49 & 4,44 \\
\hline $\mathrm{HCP}_{0,95}$ & 1,2 & 0,9 & 0,7 & \\
\hline
\end{tabular}


величина получаемой прибавки урожая снижалась. На контрольном варианте прибавка урожая товарных початков от орошения составила 9,6 т/га или $89 \%$, в т. ч. зерна - 4,18 т/га или $94 \%$, а на втором варианте она возросла соответственно до 12,3 и 5,55 т/га, что в процентном отношении составило 114 и $125 \%$.

Наименьшая прибавка урожая товарных початков - 4,8 т/га от орошения, в т. ч. зерна - 1,89 т/га или 44 и 43 \% получена на третьем варианте.

\section{Лumepamypa}

1. Применение новых гербицидов на посевах кукурузы на выщелоченных черноземах КБР / А. Ю. Кишев, И. М. Ханиева, Т. Б. Жеруков, З. Г. С. Шибзухов // European research: сборник статей XII международной научно-практической конференции. - Пенза: Наука и Просвещение (ИП Гуляев Г. Ю.), 2017. - С. 77-79.

2. Восстановитель плодородия почв / К. Г. Магомедов, И. М. Ханиева, А. Ю. Кишев, А. Л. Бозиев, Т. Б. Жеруков, З. С. Шибзухов, А. Э. Амшоков // News of Science and Education. - 2017. - Т. 11. - № 3. - С. 71-74.

3. Восстановитель плодородия почв / К.Г. Магомедов, И. М. Ханиева, А. Ю. Кишев, А. Л. Бозиев, Т. Б. Жеруков, З. Г. С. Шибзухов, А. Э. Амшоков // Fundamental and applied science2017: materials of the XIII International scientific and practical conference. - Editor: Michael Wilson, 2017. - C. 74-77.

4. Агротехнические особенности выращивания сахарной кукурузы в условиях КБР / И. М. Ханиева, Ю. М. Шогенов, Т. С. Виндугов, А. Б. Забаков // Научные достижения высшей школы 2019: сборник статей международного научно-исследовательского конкурса. - Петрозаводск, 2019. С. 62-68.

5. Ханиева, И. М. Зависимость структуры урожая гибридов кукурузы в Кабардино-Балкарии от сортовых особенностей и обработки биопрепаратами / И. М. Ханиева, Ю. М. Шогенов, 3. Г. С. Шибзухов // Технологии, инструменты и механизмы инновационного развития: материалы международной научно-практической конференции. - Самара: НИЦ «Поволжская научная корпорация», 2017. - С. 159-162.

6. Ханиева, И. М. Урожайность гибридов кукурузы в Кабардино-Балкарии в зависимости от сортовых особенностей и сроков посева / И.М.Ханиева, Ю. М. Шогенов, З. Г. С. Шибзухов // Технологии, инструменты и механизмы инновационного развития: материалы международной научно-практической конференции. - Самара: НИЦ «Поволжская научная корпорация», 2017. - С. 162-164.

7. Ханиева, И. М. Влияние сортовых особенностей и сроков посева на урожайность сахарной кукурузы в Кабардино-Балкарии / И. М. Ханиева, З. Г. С. Шибзухов, Ю. М. Шогенов // Проблемы развития АПК региона. - 2018. - № 2 (34). - С. 102-108.

8. Шогенов, Ю. М. Урожайность гибридов кукурузы в зависимости от уровня минерального питания / Ю. М. Шогенов // Современное экологическое состояние природной среды и научнопрактические аспекты рационального природопользования: материалы международной научнопрактической интернет-конференции. - Соленое Займище: Прикаспийский научно-исследовательский институт аридного земледелия, 2018. - С. 411-414.

9. Шогенов, Ю. М. Качество зерна гибридов кукурузы в зависимости от сортовых особенностей и сроков посева в Кабардино-Балкарии / Ю. М. Шогенов, 3. Г. С. Шибзухов // Технологии, инструменты и механизмы инновационного развития: материалы международной научно-практической конференции. - Самара: НИЦ «Поволжская научная корпорация», 2017. - С. 182-183.

10. Шогенов, Ю. М. Влияние уровня минерального питания на урожайность гибридов кукурузы в условиях КБР / Ю. М. Шогенов, 3. Г. С. Шибзухов, 3. Э. Уянаева // Технологии, инструменты и механизмы инновационного развития: материалы международной научно-практической конференции. - Самара: НИЦ «Поволжская научная корпорация», 2017. - С. 194-197.

11. Продолжительность межфазных периодов и ростовые процессы в зависимости от приемов возделывания в условиях Кабардино-Балкарии / Ю. М. Шогенов, З. Г. С. Шибзухов, С. С. Б. Эльмесов, Т. С. Виндугов // Научно-практические пути повышения экологической устойчивости и социально-экономическое обеспечение сельскохозяйственного производства: материалы международной научно-практической конференции, посвящённой году экологии в России. - Соленое Займище: Прикаспийский научно-исследовательский институт аридного земледелия, 2017. - С. 344-346.

Нива Поволжья $\quad$ № 1 (54) февраль 2020 
12. Эльмесов, А. М. Регулирование сорного компонента агрофитоценоза в земледелии / А. М. Эльмесов, 3. Г. С. Шибзухов //Современное экологическое состояние природной среды и научнопрактические аспекты рационального природопользования: материалы международной научнопрактической интернет-конференции. - Соленое Займище: Прикаспийский научноисследовательский институт аридного земледелия, 2017. - С. 822-825.

13. Эльмесов, А. М. Особенности обработки почвы под кукурузу / А. М. Эльмесов, 3. Г. С. Шибзухов // Современное экологическое состояние природной среды и научно-практические аспекты рационального природопользования: материалы международной научно-практической интернет-конференции. - Соленое Займище: Прикаспийский научно-исследовательский институт аридного земледелия, 2017. - С. 1113-1118.

14. Эльмесов, А. М. Продуктивность кукурузы в зависимости от послепосевной обработки почвы / А. М. Эльмесов, 3. А. Иванова // Зерновое хозяйство. - 2006. - № 5. - С. 26-27.

15. Ханиева, И. М. Особенности применения регуляторов роста на посевах кукурузы / И. М. Ханиева, 3. Г. С. Шибзухов, А. Р. Саболиров, А. М. Темиржанов // SCIENCE AND TECHNOLOGY INNOVATIONS: сборник статей международной научно-практической конференции. - Петрозаводск, 2019. - С. 105-108.

16. Ханиева, И. М. Влияние применения листовых подкормок на продуктивность кукурузы / И. М. Ханиева, Ю. М. Шогенов, 3. В. Улигов, А. Р. Алоев, А. М. Батырова, А. А. Толгурова // News of Science and Education. - 2019. - T. 3. - № 5. - C. 86-90.

UDC 633.15:631.52

DOI 10.36461/NP.2020.54.1.008

\title{
OPTIMIZATION OF THE SOIL MOISTURE CONTENT LEVEL WHEN GROWING SUGAR CORN
}

\author{
I. M. Khanieva, Doctor of Agricultural Sciences, Professor; *S. A. Bekuzarova, Doctor of Agricultural \\ Sciences, Professor; Z. G. S. Shibzukhov, Candidate of Agricultural Sciences, Assistant-professor; \\ T. S. Vindugov, post-graduate
Federal State Budgetary Educational Institution of Higher Education «Kabardino-Balkarian State Agrarian University», Russia, Nalchik, e-mail: imhanieva@mail.ru;
${ }^{*}$ Federal State Budgetary Educational Institution of Higher Education «Gorsky State Agrarian University», Russia, Vladikavkaz, e-mail: bekos37@mail.ru

The work was performed in the conditions of the submontane zone of the Kabardino-Balkarian region with insufficient and unstable moisture. Modern drip irrigation systems were used for the experiments. The results of the experiments show how irrigation has an effect on the development and productivity of sweet corn plants. The studies used five variants of the irrigation level. After analyzing the data obtained, the most optimal irrigation rate was identified and recommended to be used in the future for the production of sugar corn. Observations showed that at the beginning of the growing season, the growth phases of sugar corn plants were the same for all variants, the emergence of seedlings was noted on 8-11 days during the years of research. Later, with changes in moisture conditions, there was a difference in the dates of onset of the main phases of vegetation. In the second variant, the growth phases almost coincided with the control variant, but the phases of corn cobs flowering and technical ripeness enlarged by one day. In the third and fourth variants, the main phases of vegetation were reduced by 1-2 days in comparison with the control. In the non-irrigated version, the most accelerated development of this crop took place, and technical ripeness occurred 4-7 days earlier than in other versions of the experiment. The increase in yield depending on the level of irrigation followed the same pattern - with a decrease in the level of correspondence of the amount of received moisture to the needs of plants, the value of the resulting crop increase decreased. In the control version, the increase in the yield of commercial corn cobs from irrigation was $9.6 \mathrm{t} /$ ha or $89 \%$, including grain $-4.18 \mathrm{t} / \mathrm{ha}$ or $94 \%$, and in the second version, it increased to 12.3 and $5.55 \mathrm{t} /$ ha respectively, which in percentage terms amounted to 114 and $125 \%$.

Keywords: moisture content, plant development, sugar corn, yield, plant survival, interphase periods.

\section{References:}

1. Application of new herbicides on corn plantings on leached chernozems of the KabardinoBalkarian region / A. Yu. Kishev, I. M. Khanieva, T. B. Zherukov, Z. G. S. Shibzukhov // European research: collection of articles of the XII international scientific and practical conference. - Penza: Science and Education (IP Gulyaev G. Yu.), 2017. - p. 77-79.

2. Soil fertility restorer / K. G Magomedov, I. M. Khanieva, A. Yu. Kishev, A. L. Boziev, T. B. Zherukov, Z. S. Shibzukhov, A. E. Amshokov // News of Science and Education. - 2017. - Vol. 11. - No. 3. - p. 71-74. 
3. Soil fertility restorer / K. G Magomedov, I. M. Khanieva, A. Yu. Kishev, A. L. Boziev, T. B. Zherukov, Z. G. S. Shibzukhov, A. E. Amshokov // Fundamental and applied science-2017: materials of the XIII International scientific and practical conference. -Editor: Michael Wilson, 2017. - p. 74-77.

4. Agrotechnical features of growing sugar corn in the Kabardino-Balkarian region conditions / I. M. Khanieva, Yu. M. Shogenov, T.S. Vindugov, A. B. Zabakov // Scientific achievements of the higher school 2019: collection of articles of the international research competition. - Petrozavodsk, 2019. p. 62-68.

5. I. M. Khanieva, Dependence of the crop structure of corn hybrids in the Kabardino-Balkarian region on varietal features and processing with biological products / I. M. Khanieva, Yu. M. Shogenov, Z. G. S. Shibzukhov // Technologies, tools and mechanisms of innovative development: materials of the international scientific and practical conference. - Samara: Center for Scientific Research «Povolzhskaya nauchnaya korporatsiya», 2017. - p. 159-162.

6. I. M. Khanieva, Productivity of corn hybrids in the Kabardino-Balkarian region depending on varietal features and terms of sowing / I. M. Khanieva, Yu. M. Shogenov, Z. G. S. Shibzukhov // Technologies, tools and mechanisms of innovative development: materials of the international scientific and practical conference. - Samara: Center for Scientific Research «Povolzhskaya nauchnaya korporatsiya», 2017. - p. 162-164.

7. I. M. Khanieva, Effect of the varietal features and sowing time on the yield of sugar corn in the Kabardino-Balkarian region / I. M. Khanieva, Z. G. S. Shibzukhov, Yu. M. Shogenov // Problems of development of Agro-Industrial Complex in the region. - 2018. - No. 2 (34). - p. 102-108.

8. Yu. M. Shogenov, Productivity of corn hybrids depending on the level of mineral nutrition / Yu. M. Shogenov // Modern ecological state of the natural environment and scientific and practical aspects of rational nature management: materials of the International scientific and practical Internet conference. -Solenoe Zajmishche: Pre-Caspian Scientific Research Institute of Arid agriculture, 2018. - p. 411-414.

9. Yu. M. Shogenov, Quality of corn hybrids grain depending on varietal features and terms of sowing in the Kabardino-Balkarian region / Yu. M. Shogenov, Z. G. S. Shibzukhov // Technologies, tools and mechanisms of innovative development: materials of the international scientific and practical conference. - Samara: Center for Scientific Research «Povolzhskaya nauchnaya korporatsiya», 2017. p. $182-183$.

10. Yu. M. Shogenov, Influence of the level of mineral nutrition on the yield of corn hybrids in the Kabardino-Balkarian region / Yu. M. Shogenov, Z. G. S. Shibzukhov, Z. E. Uyanaeva // Technology, tools and mechanisms of innovative development: materials of the international scientific and practical conference. - Samara: Center for Scientific Research «Povolzhskaya nauchnaya korporatsiya», 2017. p. 194-197.

11. Duration of interphase periods and growth processes depending on cultivation techniques in the Kabardino-Balkarian region / Yu. M. Shogenov, Z. G. S. Shibzukhov, S. S. B. Elmesov, T. S. Vindugov // Scientific and practical ways to improve environmental sustainability and socio-economic support of agricultural production: materials of the International scientific and practical conference dedicated to the year of Ecology in Russia. - Solenoe Zajmishche: Pre-Caspian Scientific Research Institute of Arid agriculture, 2017. - p. 344-346.

12. A. M. Elmesov, Regulation of the weed component of agrophytocenosis in agriculture / A. M. Elmesov, Z. G. S. Shibzukhov // Modern ecological state of the natural environment and scientific and practical aspects of rational nature management: materials of the International scientific and practical Internet conference. -Solenoe Zajmishche: Pre-Caspian Scientific Research Institute of Arid agriculture, 2017. - p. 822-825.

13. A. M. Elmesov, Features of soil processing for corn / A. M. Elmesov, Z. G. S. Shibzukhov // Modern ecological state of the natural environment and scientific and practical aspects of rational nature management: materials of the International scientific and practical Internet conference. -Solenoe Zajmishche: Pre-Caspian Scientific Research Institute of Arid agriculture, 2017. - p. 1113-1118.

14. A. M. Elmesov, The productivity of corn depending on post-seeding cultivation of the soil / A. M. Elmesov, Z. A. Ivanova // Zernovoe hozyajstvo. - 2006. - No. 5. - p. 26-27.

15. Khanieva, I. M., Khanieva, Features of using growth regulators on corn crops / I. M. Khanieva, Z. G. S. Shibzukhov, A. R. Sabolirov, A. M. Temirzhanov // SCIENCE AND TECHNOLOGY INNOVATIONS: collection of articles of the international scientific and practical conference. - Petrozavodsk, 2019. - p. 105-108.

16. I. M. Khanieva, Effect of foliar dressing on corn productivity / I. M. Khanieva, Yu. M. Shogenov, Z. V. Uligov, A. R. Aloev, A. M. Batyrova, A. A. Tolgurova // News of Science and Education. - 2019. Vol. 3. - No. 5. - p. 86-90. 